\title{
Transmission of Six Ampeloviruses and Two Vitiviruses to Grapevine by Phenacoccus aceris
}

\author{
J. Le Maguet, M. Beuve, E. Herrbach, and O. Lemaire
}

First author: Comité Interprofessionnel du Vin de Champagne, 5 rue Henri Martin, BP 135, F-51200 Epernay, France; and first, second, third, and fourth authors: INRA, UMR1131 Santé de la Vigne et Qualité du Vin, F-68000 Colmar, France, and Université de Strasbourg, UMR1131, F-67000 Strasbourg, France.

Accepted for publication 19 March 2012.

\begin{abstract}
Le Maguet, J., Beuve, M., Herrbach, E., and Lemaire, O. 2012. Transmission of six ampeloviruses and two vitiviruses to grapevine by Phenacoccus aceris. Phytopathology 102:717-723.

Grapevine leafroll disease is caused by grapevine leafroll-associated viruses (GLRaVs). These viruses are common in vineyards worldwide and often associated with vitiviruses that are involved in the rugose wood complex of grapevine. Ten mealybug species are known as vectors of one or several of these grapevine viruses, including the apple mealybug Phenacoccus aceris which is widespread in Holarctic regions and able to

by Phenacoccus aceris in order to better understand the contribution of this mealybug to leafroll epidemics. Results showed that Phenacoccus aceris is able to transmit GLRaV-1, $-3,-4,-5,-6$, and -9 to grapevine but not GLRaV-7. This is the first report of GLRaV-6 transmission by a mealybug. Also, for the first time it was shown that Phenacoccus aceris could vector vitiviruses Grapevine virus A (GVA) and Grapevine virus B (GVB). First instar nymphs were the most efficient stage in transmitting GLRaV-1, -3, and GVA. This research sheds light on the transmission biology of grapevine viruses by Phenacoccus aceris and represents a step forward to leafroll disease management.
\end{abstract} transmit Grapevine leafroll-associated virus-1 and -3 (GLRaV-1 and -3). Our aim was to characterize the transmission features of leafroll viruses
Additional keywords: Betaflexiviridae, Closteroviridae, Vitis.
Grapevine leafroll disease is becoming one of the most widespread and damaging viral diseases in grapevine growing areas worldwide (25). It affects all grapevine rootstocks and Vitis vinifera varieties, reducing yield and grape quality (9). Leafroll symptoms are characterized by downward rolling of the leaf margins, interveinal reddening of leaves in red-berried varieties and increased leaf thickness. The disease is caused by at least 11 serologically distinct grapevine leafroll-associated viruses (GLRaVs), all members of the family Closteroviridae. Most leafroll viruses (GLRaV-1, -3, -4, -5, -6, -9, -Pr, -De, and Grapevine leafroll-associated Carnelian virus [GLRaCV]) belong to the genus Ampelovirus, whereas GLRaV-2 is a member of the genus Closterovirus and GLRaV-7 is awaiting for a new genus assignment (16). All these viruses have long filamentous particles containing a positive-sense, single-stranded RNA molecule. Among leafroll-associated viruses, GLRaV-3 is the most widespread in vineyards worldwide, especially in Mediterranean climates (9). Grapevine leafroll viruses are graft-transmissible and persist in propagative material (budwood, rootstocks, and grafted vines). Thus, the worldwide expansion of leafroll is mainly attributed to the exchange of infected plant material, especially asymptomatic rootstocks (8). However, natural spread of leafroll in vineyards has also been described in many regions $(7,13,31)$, where studies revealed a constant increase in the prevalence of leafroll and an association with mealybug (family Pseudococcidae) infestation. Transmission of GLRaV by mealybugs in laboratory conditions was first reported in 1990 (11). Since then, many field surveys and laboratory experiments showed that several mealybugs, as well as soft scale (family Coccidae) species are involved in transmission of GLRaVs. Currently, at least nine mealybug

Corresponding author: J. Le Maguet; E-mail address: jean.le-maguet@orange.fr

http://dx.doi.org/10.1094/PHYTO-10-11-0289

(C) 2012 The American Phytopathological Society species (Heliococcus bohemicus, Phenacoccus aceris, Planococcus citri, Planococcus ficus, Pseudococcus calceolariae, Pseudococcus comstocki, Pseudococcus longispinus, Pseudococcus maritimus, and Pseudococcus viburni) and seven soft scale species (Ceroplastes rusci, Coccus longulus, Neopulvinaria innumerabilis, Parthenolecanium corni, Pulvinaria vitis, Parasaissetia nigra, and Saissetia sp.) have been reported to vector one or more GLRaV species (21). So far no vector has been identified for GLRaV-2, -6, -7, -Pr, -De, and GLRaCV (44). Leafroll viruses are phloem-limited pathogens and their mode of transmission by vectors is semipersistent (43). Vines are frequently coinfected by one or more GLRaV species. These viruses are often associated with Grapevine virus A (GVA) and Grapevine virus $B(\mathrm{GVB})$ that are involved in the rugose wood disease complex, in particular in the Kober stem grooving and corky bark syndromes, respectively (24). GVA, GVB, and Grapevine virus E (GVE) from the genus Vitivirus in the family Betaflexiviridae are vectored by several mealybug and soft scale species $(15,28$, 34,46).

To date in France, only GLRaV-1, -2, -3, and GVA have been identified in naturally infected vineyards (5) and nine scale insect species are commonly observed on grapevine: $N$. innumerabilis, Parthenolecanium corni, Parthenolecanium persicae, Pulvinaria vitis (family Coccidae), Targionia vitis (family Diaspididae), $H$. bohemicus, Phenacoccus aceris, Planococcus citri, and Planococcus ficus (family Pseudococcidae) (37). Among these, the mealybug Phenacoccus aceris is able to transmit three different ampeloviruses; GLRaV-1 and -3 to grapevine (38) and LChV-2 (Little cherry virus-2) to cherry (32). Phenacoccus aceris is a common Holarctic mealybug that feeds on a wide range of perennial hosts (17). In Europe, this species is univoltine with females and males having three and four instar nymphs, respectively. Adult females appear in late spring and lay numerous eggs in a cottony egg sac within bark cracks of the host plant, especially grapevine. Phenacoccus aceris has been reported in 
French vineyards, especially in Burgundy where it infests vines heavily affected by GLRaV-1 and GVA. This mealybug is suspected to play a major role in the natural spread of GLRaV-1 and $-3(18,38)$ in vineyards. The purpose of this study was to extensively characterize the capability of Phenacoccus aceris to transmit grapevine viruses. To address this question, transmission experiments of GLRaV-1, -3, -4, -5, -6, -7, -9, GVA, and GVB were performed. Furthermore, the vector capacity of different life stages of Phenacoccus aceris was explored.

\section{MATERIALS AND METHODS}

Virus sources. Virus source vines were rooted in a greenhouse from 12 accessions of field-collected dormant canes (Reference collection of grapevine viruses and virus-like diseases, INRA, France) and were used as mother-plants for infected leaf sampling. Virus content of the 12 accessions (PN01, PN02, PN03, P70, Y199, Y217, Y252, Y258, Y276, Y318, Cab119-66, and TE132; Table 1) was checked by double-antibody sandwich enzymelinked immunosorbent assay (DAS-ELISA) and by reverse transcription polymerase chain reaction (RT-PCR). To avoid infestation by insects, the plants were regularly sprayed with insecticide until 1 month prior to acquisition experiments.

Recipient grapevines. A red-berried variety, Vitis vinifera 'Pinot noir', clone 115 (P115), frequently planted in vineyards of Alsace, Champagne, and Burgundy, was used as the recipient vine for transmission tests. The virus-free status of P115 was ascertained by reverse transcription-polymerase chain reaction (RT-PCR) prior to running the experiments. Virus-free plants were rooted from greenhouse cuttings made in spring and grown individually in pots. Recipient vines were regularly sprayed bimonthly with an insecticide (alternatively Confidor $0.35 \mathrm{ml} / \mathrm{liter}$, Kiros $1 \mathrm{~m} / \mathrm{liter}$, or Fuoro $3 \mathrm{ml} / \mathrm{liter}$ ) until 1 month prior to inoculation to avoid infestation of test plants by insects. After inoculation, recipient vines were grown in a greenhouse and then placed at $4^{\circ} \mathrm{C}$ for 1 month in order to reproduce winter dormancy period.

Phenacoccus aceris colony. Colonies of Phenacoccus aceris (Signoret) were laboratory reared in spring on virus-free sprouting potatoes, starting from field-collected gravid females (vineyard of Bonzon, Burgundy, France). Morphological identification of the species was made by J.-F. Germain (ANSES, Laboratoire National de la Protection des Végétaux, Montpellier, France). The species identification was ascertained by molecular characteri- zation using a set of markers able to efficiently distinguish taxa within Pseudococcidae (22). Insects were maintained in darkness at $23^{\circ} \mathrm{C}\left( \pm 2^{\circ} \mathrm{C}\right)$ in plastic jars whose lids had been perforated and covered with a $28 \mu \mathrm{m}$ mesh tissue to enable air circulation.

Virus transmission by Phenacoccus aceris. To determine the ability of Phenacoccus aceris to acquire and inoculate GLRaV-1, $-3,-4,-5,-6,-7,-9$, GVA, and GVB to grapevine, transmission assays were conducted from June to August (experiments A to H). Leaves of eight accessions of virus source vines were collected from greenhouse-grown mother-plants and distributed individually in transparent jars. The petiole of each leaf was placed into small wet cotton pieces to ensure continuous water supply during the acquisition access period (AAP). Straight after hatching, first instar nymphs (L1) were gently collected and transferred into the jars containing leaves of source vines to provide access to the virus. Following a $48 \mathrm{~h}$ AAP, batches of approximately 50 mealybugs were transferred onto each recipient vine, which were individually enclosed in a microperforated plastic bag. Each transmission test was made with 20 recipient vines. Recipient vines were placed at $25^{\circ} \mathrm{C}\left( \pm 3^{\circ} \mathrm{C}\right), 16 / 8 \mathrm{~h}$ (light/dark) under artificial light. One recipient vine per assay was maintained under the same conditions with 50 mealybugs collected from the healthy Phenacoccus aceris colony. In addition, batches of 10 mealybugs were collected after AAP of each transmission assay and stored in 1.5-ml Eppendorf tubes with $150 \mu$ of RLT buffer (RNeasy Plant Mini Kit; Qiagen, France) containing 1\% $\beta$-mercaptoethanol. Tubes were kept at $-20^{\circ} \mathrm{C}$ before total RNA extraction and detection of viruses by RT-PCR. After an inoculation access period (IAP) of $48 \mathrm{~h}$, plastic bags were removed and plants were sprayed with mevinphos (Phosdrin W10 at $4 \mathrm{ml} /$ liter) to kill the mealybugs. Recipient vines were kept in laboratory conditions for 1 week to ascertain the absence of mealybugs and then transferred to the greenhouse.

Determination of transmission efficiency of first and second instar nymphs of Phenacoccus aceris from laboratory-reared colony. We performed experiments on first (L1) and second (L2) instar nymphs of Phenacoccus aceris for virus transmission efficiency (experiments I to L). Aviruliferous mealybugs were collected from a laboratory-reared colony and placed, as described above, in jars containing source vines for an AAP of $48 \mathrm{~h}$. This experiment was performed with four accessions of virusinfected Pinot noir: PN01 and P70 (GLRaV-1 and GVA) and PN02 and PN03 (GLRaV-1, -3, and GVA). These source vines were tested by double-antibody sandwich enzyme-linked immuno-

TABLE 1. Mean absorbance values of enzyme-linked immunosorbent assay on tissue of source vines used for transmission experiments

\begin{tabular}{|c|c|c|c|c|c|c|c|c|c|}
\hline \multirow[b]{2}{*}{ Experiments ${ }^{\mathrm{a}}$} & \multirow[b]{2}{*}{ Source plants ${ }^{b}$} & \multicolumn{8}{|c|}{ ELISA OD $_{405}$ values $^{c}$} \\
\hline & & GLRaV-1 ${ }^{\mathrm{d}}$ & GLRaV-3 & GLRaV-4 & GLRaV-5 & GLRaV-6 & GLRaV-7 & GLRaV-9 & GVA \\
\hline A & Yhsouh ali Y318 & 2.015 & 1.045 & - & - & - & - & - & 1.000 \\
\hline $\mathrm{B}$ & Vardabouïre Y258 & 1.960 & 1.245 & - & - & - & - & - & 0.955 \\
\hline $\mathrm{C}$ & Chardonnay TE132 & 1.410 & - & - & - & - & - & - & - \\
\hline $\mathrm{D}$ & Koudsi Y252 & - & - & 1.895 & - & - & - & - & 0.875 \\
\hline $\mathrm{E}$ & Black Monukka Y199 & - & - & - & 0.940 & 0.870 & - & - & 0.695 \\
\hline $\mathrm{F}$ & White Emperor Y217 & - & - & - & 1.575 & - & - & - & 0.740 \\
\hline $\mathrm{G}$ & Otcha Bala Y276 & - & - & - & - & - & 1.260 & - & 1.150 \\
\hline $\mathrm{H}$ & Cabernet Cab119-66 & - & - & - & - & - & - & 1.320 & 1.350 \\
\hline $\mathrm{I}, \mathrm{J}$ & Pinot noir P70 & 2.110 & - & - & - & - & - & - & 1.360 \\
\hline $\mathrm{I}, \mathrm{J}$ & Pinot noir PN01 & 1.220 & - & - & - & - & - & - & 0.950 \\
\hline $\mathrm{K}, \mathrm{L}$ & Pinot noir PNO2 & 1.260 & 1.645 & - & - & - & - & - & 0.915 \\
\hline $\mathrm{K}, \mathrm{L}$ & Pinot noir PN03 & 1.280 & 1.730 & - & - & - & - & - & 1.090 \\
\hline $\mathrm{M}$ & Pinot noir (spring) & 2.220 & 1.535 & - & - & - & - & - & 0.995 \\
\hline $\mathrm{N}$ & Pinot noir (early summer) & 2.090 & 1.800 & - & - & - & - & - & 1.285 \\
\hline $\mathrm{O}$ & Pinot noir (late summer) & 1.785 & 1.730 & - & - & - & - & - & 1.040 \\
\hline $\mathrm{P}$ & Pinot noir (winter) & 2.260 & 2.255 & - & - & - & - & - & 1.490 \\
\hline
\end{tabular}

a Tissues tested were mature leaves for experiments A to L and O, young leaves for experiments $\mathrm{M}$ and $\mathrm{N}$, and phloem scrapings of wood for experiment $\mathrm{P}$.

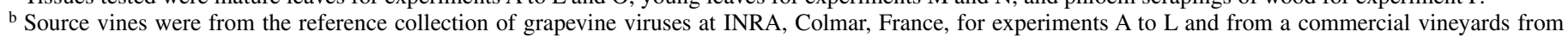
experiments $\mathrm{M}$ to $\mathrm{P}$.

c Absorbance values were adjusted after deducting absorbance values of blank controls.

d Abbreviations: GLRaV, Grapevine leafroll-associated virus; GVA, Grapevine virus A. 
sorbent assay (DAS-ELISA) in order to compare the virus titer in each accession regarding standard titration. Mealybugs were gently transferred from source leaves to recipient vines using a fine brush, and in batches of 20 individuals for a $48 \mathrm{~h}$ IAP. We used 20 recipient grapevines for each virus source and mealybug life stage. Recipient vines were then treated as described above.

Transmission efficiency analysis and estimation of individual infection rates. Transmission efficiencies were compared using $\chi^{2}$ tests between the two life stages of Phenacoccus aceris and between the four leafroll accessions. The probability that a single mealybug was a vector was estimated using Burrows' formula (6): $\mathrm{p}_{\mathrm{B}}=1-[(2 k R+k-1) /(2 k N+k-1)]^{1 / k}$, where $N$ is the total of test plants, $R$ is the number of negative plants, and $k$ is the number of individuals per plant.

Assessment of transmission efficiency of field-collected Phenacoccus aceris from naturally infected grapevines. We tested the ability of field populations of Phenacoccus aceris to transmit leafroll viruses and GVA in vineyards (experiments $M$ to P). Vine sources of GLRaV-1, -3, and GVA were identified by DAS-ELISA in a commercial vineyard (Bonzon, Burgundy, France). Populations of Phenacoccus aceris were sampled on these vines between May 2010 and February 2011. Four developmental stages were used in transmission assays; adult females, L1, and L2 instar nymphs were taken from infected vine leaves or stems, whereas L3 instar nymphs were collected during winter in their cocoons beneath the bark. Immediately after collection, batches of 20 mealybugs were gently transferred with a fine brush onto each recipient vine for a $48 \mathrm{~h}$ IAP. We used 30 recipient grapevines for each transmission assay. Batches of 20 mealybugs of each life stage were collected from infected vines and conserved at $-20^{\circ} \mathrm{C}$ in $150 \mu$ of RLT buffer containing $1 \% \beta$-mercaptoethanol for subsequent RNA extraction and RT-PCR analyses. Recipient vines were then treated as described previously.

Virus detection. Leaves of recipient vines were all tested by DAS-ELISA, except for plants inoculated with GVB which were tested by RT-PCR (2). Detection tests were first made 3 months after transmission experiments on blades of both mature and young leaves. After an artificial dormancy period of 5 weeks at $4^{\circ} \mathrm{C}$, plants were retested 7 months after transmission by DASELISA made on young leaves and petioles. Polyclonal antibodies produced in our laboratory were used for the detection of GLRaV$1,-5,-7$, and GVA in a biotin-streptavidin procedure (45). Detection of GLRaV-3, -4, and -6 was performed using commercial antisera (Bioreba AG, Basel, Switzerland) following the manufacturer's instructions. Detection of GLRaV-9 was performed with monoclonal antibodies provided by S. Besse (ACW, Nyon, Switzerland). Total RNA extraction was performed using RNeasy Plant Mini kit (Qiagen, France), as described by Beuve et al. (3), for all control tubes containing postacquisition sampled mealybugs. A multiplex RT-PCR assay (2) was used for the simultaneous detection of GRLaV-1, -3, and GVA and one step conventional RT-PCR (3) was performed for testing GLRaV-4, -5, -6, $-7,-9$, and GVB in control mealybug samples.

\section{RESULTS}

Virus transmission by Phenacoccus aceris. Phenacoccus aceris voucher Bz12 partial sequences of cytochrome oxidase subunit I gene (COI), 28S ribosomal RNA gene, and internal transcribed spacer 2 (ITS2) gene are available in a genomic sequence database (GenBank accessions nos. JN546624, JN546625, and JN546626). Transmission experiments were performed to assess the ability of Phenacoccus aceris to transmit nine grapevine viruses. Mean absorbance values obtained by DAS-ELISA in the source vines are presented in Table 1. Ampeloviruses GLRaV-1, -3, -4, -5, -6, and -9, and vitiviruses GVA and GVB were all transmitted by Phenacoccus aceris, whereas GLRaV-7 was not (Table 2). Healthy control vines used in each transmission assay tested negative for all viruses. RT-PCR performed on RNA extracted from batches of control mealybugs sampled after acquisition proved that all viruses were acquired except for GLRaV-7 (data not shown).

In experiment A, Phenacoccus aceris efficiently transmitted GLRaV-1, -3, and GVA. Seven recipient vines out of 20 were mixed-infected with GLRaV-1, -3, and GVA and nine were doubleinfected with GLRaV-3 and GVA. Two vines were infected with only GVA, as shown by DAS-ELISA. GLRaV-1, -3, and GVA were transmitted in experiment $\mathrm{B}$, but with a lower efficiency when compared with experiment $\mathrm{A}$. In experiment $\mathrm{C}, 18$ plants out of 26 were infected with GLRaV-1, among which seven were infected with GVB. Experiment D showed that Phenacoccus aceris transmitted GLRaV-4 to four plants, but GVA was not cotransmitted. In experiments E and F, GLRaV-5 was transmitted to nine recipient vines and cotransmitted with GLRaV-6 to three recipient vines; no transmission of GVA was observed in these two assays. In experiment $G$, none of the 20 recipient vines were

TABLE 2. Transmission experiments performed with 50 first instar nymphs (L1) of Phenacoccus aceris per recipient vine with acquisition and inoculation access periods of $48 \mathrm{~h}$

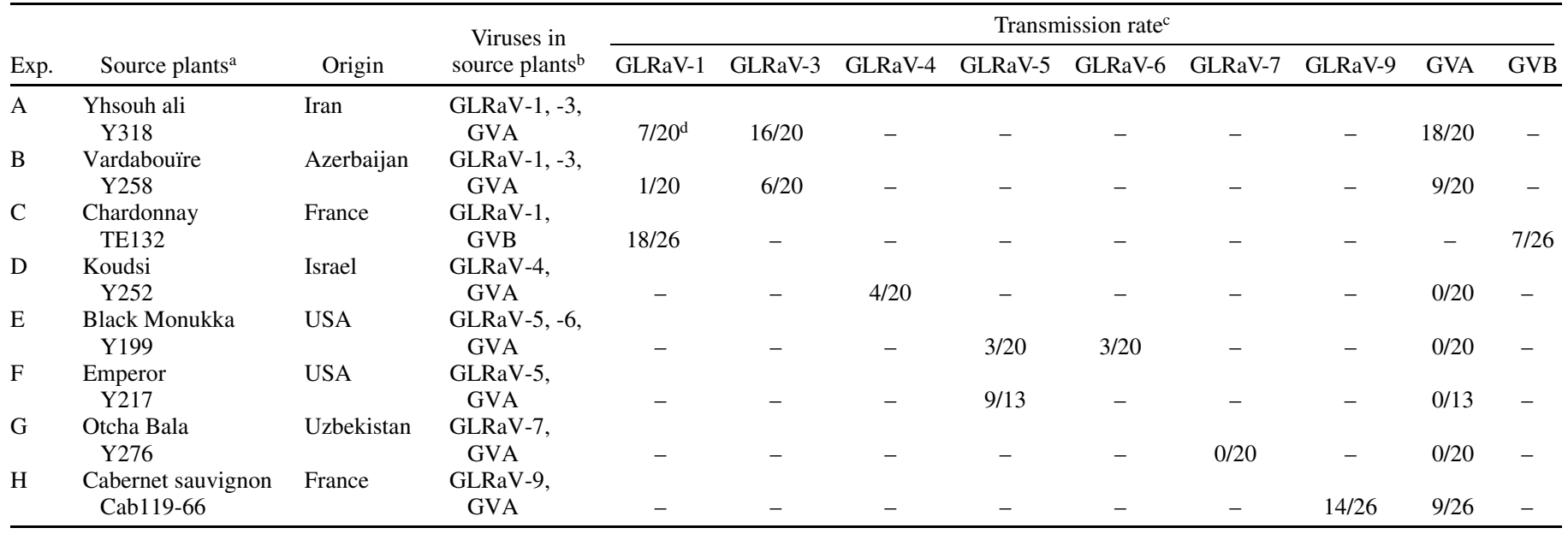

a Source vines were from the reference collection of grapevine viruses at INRA, Colmar, France.

b Abbreviations: GLRaV, Grapevine leafroll-associated virus; GVA, Grapevine virus A; GVB, Grapevine virus B.

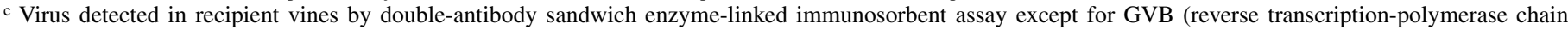
reaction).

d Number of positive plants/number of inoculated plants. 
positive to GLRaV-7 or GVA. Experiment H proved that Phenacoccus aceris efficiently transmitted GLRaV-9 with 14 positive plants out of 26, among which eight were coinfected with GVA.

Determination of transmission efficiency of first and second instar nymphs of Phenacoccus aceris from laboratory-reared colony. The mealybug life stage had an important effect on GLRaV-1, -3 , and GVA transmission. The $\chi^{2}$ test revealed a significant difference between experiments $\mathrm{I}$ and $\mathrm{J}(P=0.023$ [GLRaV-1], $P=0.003$ [GVA], Table 3, experiments I and J) and between experiments $\mathrm{K}$ and $\mathrm{L}(P<0.001$ [GLRaV-1], $P=0.025$ [GLRaV-3], $P<0.001$ [GVA], Table 3, experiments $\mathrm{K}$ and L). In addition, individual infection rates given by Burrows' estimator $\mathrm{p}_{\mathrm{B}}$ showed a higher probability for a single L1 to transmit GLRaV-1, -3 , and GVA than a single L2 (Table 3). Values of $\mathrm{p}_{\mathrm{B}}$ are at least two times higher for L1 (from 0.038 to 0.53 ) than for L2 (from 0.009 to 0.023 ). The transmission rates were similar between source grapevines. Furthermore, DAS-ELISA revealed a similar virus titer in the four accessions. The $\chi^{2}$ test was not significant between PN01 and P70 nor between PN02 and PN03 (values not shown).

Assessment of transmission of GLRaV-1, -3, and GVA by mealybugs collected from naturally infected grapevines. Experiments $\mathrm{N}$ and $\mathrm{O}$, performed with $\mathrm{L} 1$ and $\mathrm{L} 2$ instars, respectively, showed efficient transmission of GLRaV-1, -3, and GVA by field-collected populations of Phenacoccus aceris (Table 4). No virus was detected in recipient vines inoculated using adult females and L3. The transmission rates obtained with first and second instar nymphs were significantly different for GLRaV-3 and GVA ( $\chi^{2}$ test, $P=0.008$ [GLRaV-3], $P=0.03$ [GVA]) but not for GLRaV-1. Virus presence was tested by multiplex RT-PCR in mealybugs collected from infested vines in a vineyard. Viruses GLRaV-1, -3, and GVA were detected in L1 and L2 instars of
Phenacoccus aceris but not in L3 (Table 4). GLRaV-3 was detected in adult females of Phenacoccus aceris, but with a very faint signal.

\section{DISCUSSION}

This study is the first report on GLRaV-6 transmission by a mealybug. Although this ampelovirus was suspected to be mealybug-borne, its vector was unknown until now and no study had focused on its transmission, probably due to its restricted distribution in vineyards. To our knowledge, GLRaV-6 has been found only around the Mediterranean basin (20). In our experiments, GLRaV-6 was transmitted in association with GLRaV-5 from the mixed-infected accession Y199. GLRaV-5 was also transmitted from the mono-infected accession Y217. As GLRaV-5 and -6 are two related ampeloviruses both classified in the subgroup I (23), recipient vines were assayed for both viruses by specific RT-PCR in order to confirm the results obtained by DAS-ELISA. GLRaV5 is known to be vectored by Planococcus ficus, Pseudococcus longispinus, and Ceroplastes rusci $(21,39)$. Our results add Phenacoccus aceris as a new vector of this virus.

We also evaluated the capability of Phenacoccus aceris to transmit GLRaV-9, which is closely related to GLRaV-5 (23). Known vectors of GLRaV-9 are Planococcus ficus, Pseudococcus longispinus, and $C$. rusci $(21,39,44)$. We showed that Phenacoccus aceris is an efficient vector of GLRaV-9. For this experiment, the use of batches of 50 mealybugs per recipient vine during IAP probably explains why the GLRaV-9 transmission rate was three times higher than those previously reported when using batches of 20 Pseudococcus longispinus or Planococcus ficus (44). Our study shows that Phenacoccus aceris was able to transmit GLRaV-4, which confirms the transmission of this virus

TABLE 3. Comparative transmission of Grapevine leafroll-associated virus-1 and -3 (GLRaV-1 and -3) and Grapevine virus A (GVA) of L1 and L2 nymphs of Phenacoccus aceris with acquisition and inoculation access periods of $48 \mathrm{~h}$

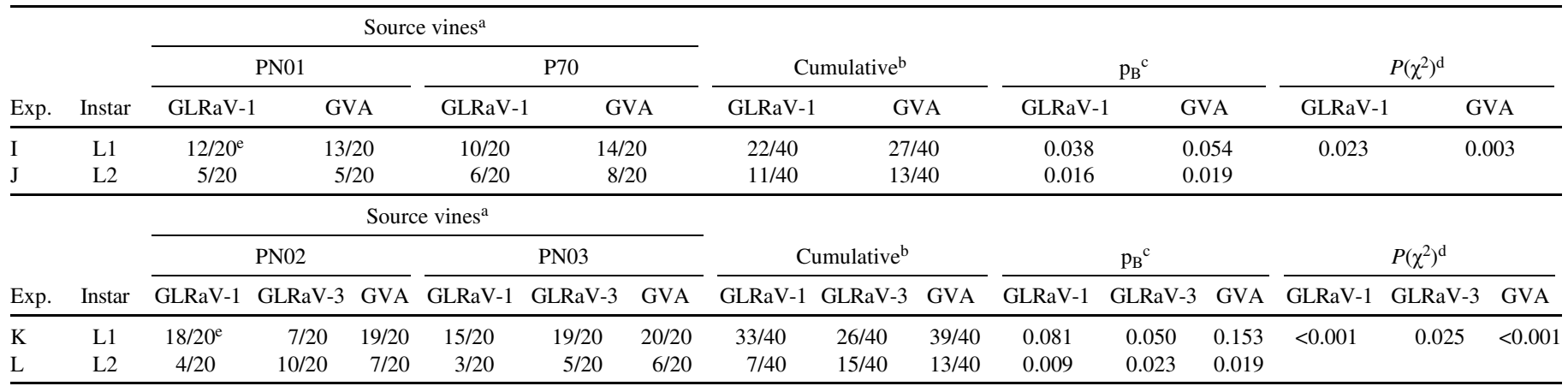

${ }^{a}$ Source vines were from the reference collection of grapevine viruses at INRA, Colmar, France.

${ }^{\mathrm{b}}$ Cumulative transmission rate independent from the source vine.

${ }^{c}$ The probability, $\mathrm{p}_{\mathrm{B}}$, that a single insect had transmitted the virus is calculated with Burrows' estimate. Estimates were calculated from total rates obtained for each virus species.

d Significance of differences in transmission efficiency between first and second instars $\left(\chi^{2}\right.$ test).

e Transmission rate obtained after virus detection in recipient vines by double-antibody sandwich enzyme-linked immunosorbent assay.

TABLE 4. Transmission efficiency of Grapevine leafroll-associated virus-1 and -3 (GLRaV-1 and -3) and Grapevine virus A (GVA) by Phenacoccus aceris collected from field naturally infected vines with inoculation access period of $48 \mathrm{~h}$

\begin{tabular}{|c|c|c|c|c|c|c|c|c|c|c|c|}
\hline \multirow[b]{2}{*}{ Exp. } & \multirow[b]{2}{*}{ Inoculation date ${ }^{\mathrm{a}}$} & \multirow[b]{2}{*}{ Growth stage } & \multicolumn{3}{|c|}{ Detection in mealybugs $^{\mathrm{b}}$} & \multicolumn{3}{|c|}{ Transmission rate ${ }^{\mathrm{c}}$} & \multicolumn{3}{|c|}{$P\left(\chi^{2}\right)^{\mathrm{d}}$} \\
\hline & & & GLRaV-1 & GLRaV-3 & GVA & GLRaV-1 & GLRaV-3 & GVA & GLRaV-1 & GLRaV-3 & GVA \\
\hline $\bar{M}$ & 28 May 2010 & Adult female & - & $+/-$ & - & $0 / 30$ & $0 / 30$ & $0 / 30$ & & & \\
\hline $\mathrm{N}$ & 20 July 2010 & First, L1 & + & + & + & $7 / 30$ & $23 / 30$ & $19 / 30$ & 0.7 & 0.008 & 0.03 \\
\hline $\mathrm{P}$ & 3 February 2011 & Third, L3 & - & - & - & $0 / 30$ & $0 / 30$ & $0 / 30$ & & & \\
\hline
\end{tabular}

a Each recipient vine was inoculated with batches of 20 mealybugs taken from infected leaves.

${ }^{\mathrm{b}}$ Virus detection by reverse transcription-polymerase chain reaction in a batch of 20 mealybugs after RNA extraction; - no detection, +/- faint signal, + strong signal on ethidium bromide-stained agarose gel.

${ }^{c}$ Virus detected in recipient vines by double-antibody sandwich enzyme-linked immunosorbent assay.

${ }^{d}$ Significance of differences in transmission efficiency between L1 and L2 ( $\chi^{2}$ test). 
by mealybugs (44). GLRaV-4 transmission experiments relied on accession Y252 that is serologically and molecularly distinguishable from GLRaV-4 isolate LR106 (36) previously shown to be transmitted by Planococcus ficus (44). Although the same AAP and IAP durations were applied across all transmission tests, the transmission efficiency obtained for GLRaV-4 was lower compared with that of GLRaV-3, -5, or -9. In the current state of knowledge, GLRaV-4 is not an efficiently mealybug-transmissible leafroll virus species. However, since GLRaV-4 was reported in vineyards in Chile, People's Republic of China, and Spain (30), further experiments are needed to evaluate the vectoring capacity of other mealybug and soft scale species collected in these countries. Finally, we tested the ability of Phenacoccus aceris to vector GLRaV-7. As expected, no GLRaV-7 was detected by DAS-ELISA in any recipient vine, or by RT-PCR in mealybugs, suggesting that Phenacoccus aceris may not be able to acquire and/or retain this virus. Recent transmission experiments showed that parasitic dodder successfully transmits GLRaV-7 from grapevine to herbaceous hosts (26), but no insects have been shown to vector this leafroll-associated virus. The complete nucleotide sequencing of a GLRaV-7 isolate has recently confirmed its close relation with the genus Crinivirus but also showed that its molecular properties would justify classifying GLRaV-7 in a new genus (16). Criniviruses are transmitted only by whiteflies but no experiment has so far implicated these insects in GLRaV-7 transmission.

Recent studies dealing with the phylogenetic relationships of members of the genus Ampelovirus suggested that leafroll viruses of subgroup I, GLRaV-4, -5, -6, -9, -De, -Pr, and GLRaCV, might be considered as divergent isolates of the same species $(1,41)$. This proposal could imply that mealybugs would transmit indiscriminately all GLRaVs within this group. This hypothesis is confirmed by the lack of evidence of virus-vector specificity in the mealybug transmission of ampeloviruses (44). Our work with Phenacoccus aceris is consistent with these findings by showing the shared transmissibility of leafroll species within the same genus. However, in spite of homogeneous experimental conditions, transmission efficiencies obtained were quite different, and noticeably lower for GLRaV-4 and -6 compared with GLRaV-5 and -9 . The low differences between virus titer in source vines seem also unlikely to explain such variable transmission rates. The molecular mechanisms of leafroll virus transmission are not well understood, but it can be hypothesized that each ampelovirus species carries specific structural features involved in recognition with vector ligands, as shown for other invertebrate vectors (29).

Our transmission experiments were conducted with three different GLRaV-1 accessions that were mixed-infected with a vitivirus: either GVA (accessions Y258 and Y318) or GVB (accession TE132). The use of these source vines enabled us to show for the first time that Phenacoccus aceris is able to transmit GVA and GVB from vine to vine. GVA is known to be transmitted by H. bohemicus, Planococcus citri, Planococcus ficus, Pseudococcus comstocki, Pseudococcus longispinus, Parthenolecanium corni, and $N$. innumerabilis $(11,12,14,15,27,46)$ and GVB by Planococcus citri, Planococcus ficus, and Pseudococcus longispinus $(4,40)$. Thus, Phenacoccus aceris is now regarded a vector of these two rugose wood disease-associated viruses. Interestingly, transmission of GVA by Phenacoccus aceris occurred from source vines Y318, Y258, Cab119-66, PN01, PN02, PN03, and P70, but not from Y252, Y199, Y217, and Y276. Comparisons between partial nucleotide sequences of the coat protein gene of GVA isolates from accessions Y199, Y217, Y252, Y276, and Cab 119-66 did not suggest an association between genetic variability and transmission patterns. More work is needed to ascertain apparent differences in transmission efficiencies among GVA isolates. Furthermore, several authors reported previously a frequent association between GVA and GLRaV species, and a heteroassistance mechanism in transmission between ampelo- and viti- viruses had been suggested $(11,12,15)$. Nevertheless, no clear picture arises from available data and further experiments are needed to characterize the biological interactions between GVA and GLRaVs for mealybug transmission and vine infection.

Two series of detection tests were performed to assess virus content in recipient vines. The first series that was conducted 3months postinoculation revealed $24 \%$ of positive recipient grapevines. The second series, made 7-months postinoculation, a time span including a period of 5 weeks at temperature around $4^{\circ} \mathrm{C}$, has shown an increase in the number of positive recipient vines by $51 \%$. The additional months and/or the artificial dormancy applied to recipient vines thus had a positive effect on virus detectability in the plants. A low number of virus particles inoculated by the mealybugs and a putative slow viral cycle and/or movement within grapevine sieve elements and companion cells may explain why these viruses are not detected at first DASELISA testing in all recipient vines.

Our results indicate that L1 of Phenacoccus aceris transmit more efficiently the GLRaV-1, -3, and GVA than L2. Experiments performed with field-collected mealybugs during the growing season confirmed that L1 were most efficient vectors than L2, L3, and adult females for GLRaV-3 and GVA. However, field-collected L1 and L2 transmitted GLRaV-1 with the same efficiency. ELISA optical density values showed similar GLRaV-1 titers regardless of the collection time point, suggesting constant virus availability in source vines. This exception may also be explained by the competition between GLRaV-1 and -3 during acquisition by mealybugs.

Adult females and L3 of Phenacoccus aceris did not transmit leafroll viruses, in spite of similar virus titers in source vines during all transmission tests. The lack of virus transmission by later instars is probably linked to the mealybug development stage. Transmission experiments with field-collected Phenacoccus aceris were performed with dormant L3 taken directly from their cocoons after a long period of diapause at low temperature usual under a semi-continental climate. However, observations of Phenacoccus aceris third instar showed from the very end of winter, a breaking of insect diapause and a feeding activity under vine bark. The detection of GLRaV-1, -3, and GVA by RTPCR in the majority of these L3 supported this early feeding of mealybugs before spring (data not shown). It suggests that L3 become infectious after their first food intake on infected vines. Further experiments are thus needed to study the influence of first feeding on vector capacity of L3. Adult females of Phenacoccus aceris were not able to transmit leafroll viruses and GVA. Previous studies reported similarly that adult females of Planococcus ficus were unable to efficiently transmit GLRaV-3 (43). The delicate transfer of mealybugs may have disrupted the insect' stylets and could explain the failure of virus transmission. However, considering the low mobility of adult females, the spread of leafroll in vineyard is more likely to occur with first instars. Among the three immature stages of Phenacoccus aceris, L1 (or crawlers) are the most mobile and can readily be dispersed by wind. Since L1 efficiently transmit leafroll and rugose woodassociated viruses, field spread relies mostly on summer dispersal, as mentioned by Tsai et al. (42). Knowing that crawlers are the most susceptible to insecticides (10), control of Phenacoccus aceris should target L1 emergence in spring and summer.

Phenacoccus aceris is present in France and infests vineyards, orchards, and many noncultivated perennials (17,32). Many leafroll epidemic events have been reported in France, especially in Beaujolais and Burgundy, where some vineyards heavily infested by Phenacoccus aceris have been totally contaminated with leafroll within 7 years (19). Phenacoccus aceris is a cosmopolitan mealybug and is reported in many European countries, as well as in Russia, North America, Korea, and Japan (17). It was likely introduced into United States at the beginning of the 20th century (33), where it caused direct damage in apple orchards and 
disseminated little cherry disease (35) in cherry growing areas. In our study, all transmission experiments were done using a single population of Phenacoccus aceris, collected from a French vineyard infected with GLRaV-1, -3 , and GVA. We proved that in the presence of other vine sources, this local population has the capability to transmit four additional ampeloviruses and two vitiviruses. Thus, there is a potential risk of vineyard contamination with ampeloviruses and vitiviruses wherever Phenacoccus aceris is present or likely to be introduced.

\section{ACKNOWLEDGMENTS}

We thank J. Misbach and his team for having provided experimental grapevine material and C. Rodriguez for improving the English text. This research was supported by three French professional committees for viticulture: Comité Interprofessionnel du Vin de Champagne, Epernay; Bureau Interprofessionnel des Vins de Bourgogne, Beaune; and Comité Interprofessionnel des Vins d'Alsace, Colmar; and by FranceAgriMer grants (2009-47-005-104, 2009-77-030-104, and 2011-0106-001-104).

\section{LITERATURE CITED}

1. Abou Ghanem-Sabanadzovic, N., Sabanadzovic, S., Gugerli, P., and Rowhani, A. 2012. Genome organization, serology and phylogeny of Grapevine leafroll-associated viruses 4 and 6: Taxonomic implications. Virus Res. 163:120-128.

2. Beuve, M., Moury, B., Spilmont, A.-S., Sempé-Ignatovic, L., Hemmer, C., and Lemaire, O. 2009. Viral sanitary status and genetic diversity of Rupestris stem pitting-associated virus (RSPaV) in French Syrah clones exhibiting various susceptibility levels to decline. Pages 52-53 in: 16th Meeting of the International Council for the Study of Virus and VirusLike Diseases of the Grapevine, Dijon, France.

3. Beuve, M., Sempé, L., and Lemaire, O. 2007. A sensitive one-step realtime RT-PCR method for detecting Grapevine leafroll-associated virus 2 variants in grapevine. J. Virol. Methods 141:117-124.

4. Boscia, D., Savino, V., Minafra, A., Namba, S., Elicio, V., Castellano, M. A., Gonsalves, D., and Martelli, G. P. 1993. Properties of a filamentous virus isolated from grapevines affected by corky bark. Arch. Virol. 130:109-120.

5. Boudon-Padieu, E., Ridé, M., and Walter, B. 2000. L'enroulement viral. Pages 47-55 in: Maladies à Virus, Bactéries et Phytoplasmes de la Vigne. B. Walter, ed. Féret, Bordeaux, France.

6. Burrows, P. M. 1987. Improved estimation of pathogen tranmission rates by group testing. Phytopathology 77:363-365.

7. Cabaleiro, C., Couceiro, C., Pereira, S., Cid, M., Barrasa, M., and Segura, A. 2008. Spatial analysis of epidemics of Grapevine leafroll associated virus-3. Eur. J. Plant Pathol. 121:121-130.

8. Cabaleiro, C., and Segura, A. 1997. Some characteristics of the transmission of grapevine leafroll associated virus 3 by Planococcus citri Risso. Eur. J. Plant Pathol. 103:373-378.

9. Charles, J. G., Cohen, D., Walker, J. T. S., Forgie, S. A., Bell, V. A., and Breen, K. C. 2006. A review of grapevine leafroll associated virus type 3 (GLRaV-3) for the New Zealand wine industry. The Horticulture and Food Research Institute of New Zealand Ltd. (HortResearch), Client Report No. 18447.

10. Daane, K., Bentley, W., Walton, V. M., Malakar-Kuenen, R., Millar, J. G., Ingels, C. A., Weber, E. A., and Gispert, C. 2006. New controls investigated for vine mealybug. Calif. Agric. 60:31-38.

11. Engelbrecht, D. J., and Kasdorf, G. G. F. 1990. Transmission of grapevine leafroll disease and associated closteroviruses by the vine mealybug, Planococcus ficus. Phytophylactica 22:341-346.

12. Fortusini, A., Scattini, G., Prati, S., Cinquanta, S., and Belli, G. 1997. Transmission of Grapevine leafroll virus 1 (GLRaV-1) and Grapevine virus $A$ (GVA) by scale insects. In: 12th Meeting of the International Council for the Study of Virus and Virus-Like Diseases of the Grapevine, Lisbon, Portugal.

13. Golino, D. A., Weber, E., Sim, S. T., and Rowhani, A. 2008. Leafroll disease is spreading rapidly in Napa Valley vineyard. Calif. Agric. 62:156160 .

14. Goszczynski, D. E., and Jooste, A. E. C. 2003. Shiraz disease (SD) is transmitted by mealybug Planococcus ficus and associated with Grapevine virus A (GVA). Pages 219-220 in: 14th Meeting of the International Council for the Study of Virus and Virus-Like Diseases of the Grapevine, Locorotondo, Italy.

15. Hommay, G., Komar, V., Lemaire, O., and Herrbach, E. 2008. Grapevine virus A transmission by larvae of Parthenolecanium corni. Eur. J. Plant Pathol. 121:185-188.
16. Jelkmann, W., Mikona, C., Turturo, C., Navarro, B., Rott, M., Menzel, W., Saldarelli, P., Minafra, A., and Martelli, G. 2012. Molecular characterization and taxonomy of grapevine leafroll-associated virus 7. Arch. Virol. 157:359-362.

17. Kosztarab, M., and Kozar, F. 1988. Scale Insect of Central Europe. Kluwer Academic Publishers, Dordrecht, The Netherlands.

18. Le Maguet, J., Herrbach, E., Hommay, G., Beuve, M., Boudon-Padieu, E., and Lemaire, O. 2009. Monitoring of Grapevine leafroll-associated virus 1 (GLRaV-1) dispersion by the mealybug Phenacoccus aceris. Pages 283284 in: 16th Meeting of the International Council for the Study of Virus and Virus-Like Diseases of the Grapevine, Dijon, France.

19. Le Maguet, J., Herrbach, E., and Lemaire, O. 2010. L'enroulement viral de la vigne et la cochenille Phenacoccus aceris. Phytoma. La Défense des Végétaux 636:46-50.

20. Mahfoudhi, N., Digiaro, M., and Dhouibi, M. H. 2008. Incidence and distribution of grapevine leafroll-associated viruses in Tunisian vineyards. J. Phytopathol. 156:556-558.

21. Mahfoudhi, N., Digiaro, M., and Dhouibi, M. H. 2009. Transmission of grapevine leafroll viruses by Planococcus ficus (Hemiptera: Pseudococcidae) and Ceroplastes rusci (Hemiptera: Coccidae). Plant Dis. 93:9991002.

22. Malausa, T., Fenis, A., Warot, S., Germain, J.-F., Ris, N., Prado, E., Botton, M., Vanlerberghe-Masutti, F., Sforza, R., Cruaud, C., Coulou, A., and Kreiter, P. 2010. DNA markers to disentangle complexes of cryptis taxa in mealybugs (Hemiptera: Pseudococcidae). J. Appl. Entomol. 135:132-145.

23. Maliogka, V. I., Dovas, C. I., and Katis, N. I. 2008. Evolutionary relationships of virus species belonging to a distinct lineage within the Ampelovirus genus. Virus Res. 135:125-135.

24. Martelli, G. P. 1993. Rugose wood complex. Pages $45-54$ in: GraftTransmissible Diseases of Grapevine. G. P. Martelli, ed. FAO, Rome, Italy.

25. Martelli, G. P., and Boudon-Padieu, E. 2006. Directory of infectious diseases of grapevine and viroses and virus-like diseases of the grapevine. Pages 59-75 in: Bibliographic Report 1998-2004 Options méditerranéennes, Série B: Studies and Research, CIEHAM-IAMB.

26. Mikona, C., and Jelkmann, W. 2010. Replication of Grapevine leafrollassociated virus-7 (GLRaV-7) by Cuscuta species and Its transmission to herbaceous plants. Plant Dis. 94:471-476.

27. Nakano, M., Nakaune, R., and Komazaki, S. 2003. Mealybug transmission of grapevine viruses in Japan. Page 218 in: 14th Meeting of the International Council for the Study of Virus and Virus-Like Diseases of the Grapevine, Locorotondo (Bari), Italy.

28. Nakaune, R., Toda, S., Mochizuki, M., and Nakano, M. 2008. Identification and characterization of a new vitivirus from grapevine. Arch. Virol. 153:1827-1832.

29. Ng, J. C. K., and Falk, B. W. 2006. Virus-vector interations mediating nonpersistent and semipersistent transmission of plant viruses. Annu. Rev. Phytopathol. 44:183-212.

30. Padilla, C. V., Cretazzo, E., Lopez, N., Garcia de Rosa, B., Padilla, V., and Velasco, L. 2010. First report of Grapevine leafroll-accosicated virus 4 (GLRaV-4) in Spain. New Dis. Rep. 21:21.

31. Pietersen, G. 2006. Spatio-temporal distribution dynamics of grapevine leafroll disease in western cape vineyards. Page 126 in: 15th Meeting of the International Council for the Study of Virus and Virus-Like Diseases of the Grapevine, Stellenboch, South Africa.

32. Raine, J., McMullen, R. D., and Farbes, A. R. 1986. Transmission of the agent causing little cherry disease by the apple mealybug Phenacoccus aceris and the dodder Cuscuta lupuliformis. Can. J. Plant. Pathol. 8:6-11.

33. Rau, G. J. 1942. The Canadian apple mealybug, Phenacoccus aceris Signoret and its allies in Northeastern America. Can. Ent. 74:118-125.

34. Rosciglione, B., Castellano, M. A., Martelli, G. P., Savino, V., and Cannizzaro, G. 1983. Mealybug transmission of grapevine virus A. Vitis 22:331-347.

35. Rott, M. E., and Jelkmann, W. 2001. Detection and partial characterization of a second closterovirus associated with little cherry disease, Little cherry virus-2. Phytopathology 91:261-267.

36. Saldarelli, P., Cornuet, P., Vigne, E., Talas, F., Bronnenkant, I., Dridi, A. M., Andret-Link, P., Boscia, D., Gugerli, P., Fuchs, M., and Martelli, G. P. 2006. Partial characterization of two divergent variants of Grapevine leafroll-associated virus 4. J. Plant Pathol. 88:203-214.

37. Sforza, R. 2008. Les cochenilles sur la vigne: Bio-éthologie, impact agronomique, lutte et prophylaxie. Pages 188-210 in: Ravageurs de la Vigne. J. Stochel, ed. Féret, Bordeaux, France.

38. Sforza, R., Boudon-Padieu, E., and Greif, C. 2003. New mealybug species vectoring Grapevine leafroll associated viruses-1 and -3 (GLRaV-1 and -3). Eur. J. Plant Pathol. 109:975-981.

39. Sim, S. T., Rowhani, A., Alkowni, R., and Golino, D. A. 2003. Experimental transmission of Grapevine leafroll-associated viruses types 5 and 9 by longtailed mealybugs. Pages 211-212 in: 14th Meeting of the 
International Council for the Study of Virus and Virus-Like Diseases of the Grapevine, Locorotondo (Bari), Italy.

40. Tanne, E., Ben-Dov, Y., and Raccah, B. 1993. Mealybug transmission of corky bark disease and an associated virus to healthy grapevine. Pages 5960 in: 11th Meeting of the International Council for the Study of Virus and Virus-Like Diseases of the Grapevine, Montreux, Switzerland.

41. Thompson, J. R., Fuchs, M., and Perry, K. L. 2012. Genomic analysis of Grapevine leafroll associated virus-5 and related viruses. Virus Res. 163:19-27.

42. Tsai, C. W., Bosco, D., Daane, K. M., and Almeida, R. P. 2011. Effect of host plant tissue on the vector transmission of grapevine leafrollassociated virus 3. J. Econ. Entomol. 104:1480-1485.

43. Tsai, C. W., Chau, J., Fernandez, L., Bosco, D., Daane, K. M., and
Almeida, R. P. P. 2008. Transmission of Grapevine leafroll-associated virus 3 by the vine mealybug (Planococcus ficus). Phytopathology 98:1093-1098.

44. Tsai, C. W., Rowhani, A., Golino, D. A., Daane, K., and Almeida, R. P. 2010. Mealybug transmission of grapevine leafroll viruses: An analysis of virus-vector specificity. Phytopathology 100:830-834.

45. Zimmermann, D., Bass, P., Legin, R., and Walter, B. 1990. Characterization and serological detection of four closterovirus-like particles associated with leafroll disease on grapevine. J. Phytopathol. 130:205218.

46. Zorloni, A., Prati, S., Bianco, P., and Belli, G. 2006. Transmission of Grapevine virus A and Grapevine leafroll-associated virus 3 by Heliococcus bohemicus. J. Plant Pathol. 88:325-328. 